\title{
Ópera do Malandro: LEITURA DE UM DISCURSO TEATRAL
}

\section{Marco Camarotti \\ Universidade Federal de Pernambuco}

Mais do que qualquer outro texto, lembra Anne Ubersfeld, o texto de teatro é dependente das condições de sua enunciação. Realmente, nenhuma significação poderá resultar de um enunciado teatral, se acaso não for levada em conta a situação de comunicação. Diz a autora:

O exercício prático do teatro dá à palavra suas condições concretas de existência. O diálogo enquanto texto é palavra morta, não significante. 'Ler' o discurso teatral é, na falta da representação, reconstituir imaginariamente as condições de enunciação, que sozinhas permitem promover o sentido; tarefa ambígua, impossível a rigor. É que as condições de enunciação não remetem a uma situação psicológica da personagem. Elas estão ligadas ao estatuto mesmo do discurso teatral e ao fato, constitutivo, da dupla enunciação. (UBERSFELD, p. 226-227)

É aí que se situa a contradição do discurso teatral no que concerne à definição de sua tipicidade, pois ele é, a um só tempo, o discurso do emissor-autor e do emissor-personagem.

Desse modo, não serão tão-somente os dados biográficos do autor, nem tampouco a psicologia do personagem, o caminho exclusivo para se chegar à origem do sentido, pois o teatro se apresenta com dupla enunciação.

No próprio texto, é necessário observar a presença de um discurso referente, que representa o autor, e é constituído pelo conjunto das rubricas e dos nomes de lugares e personagens, e de um discurso referido, representante do personagem, constituído por tudo aquilo que é sua fala no texto. 
Nesse discurso referido, verifica-se um processo de comunicação entre personagens, dentro de um outro processo de comunicação, que é aquele entre autor e público. Na leitura do teatro, esse é um fator fundamental a ser levado em consideração, se se deseja alcançar seu sentido. Além disso, em cada um desses processos, a linguagem assume uma função conativa. Ela tanto age direta e intencionalmente na direção do público, pretendendo interferir em seu comportamento, como, na estrutura do diálogo, cada elementopersonagem age, através de sua fala, na direção do outro, numa atitude idêntica de interferência sobre o comportamento.

No diálogo, portanto, haverá sempre que se buscar as representações intermediárias, suas elipses, aquilo que lá se encontra disfarçado, sob outra aparência.

Para proceder a uma análise de um texto teatral fora da representação, o único caminho, dada a natureza própria do discurso teatral, será buscar os resultados através das falas dos personagens, levando-se em conta, naturalmente, as indicações cênicas, nomes e sobretudo aquilo que, pertinente ao sentido, não se apresenta na superfície da palavra.

A Ópera do Malandro, texto escrito por Chico Buarque de Hollanda, a partir da Ópera do Mendigo, de John Gay, e da Ópera dos Três Vinténs, de Bertolt Brecht, mostra, no desenvolvimento de todas as suas sequiências, uma preocupação temática que é essencial para a compreensão dos seus sentidos possíveis. Essa temática nada mais é do que aquilo que tem sido um dos pontos cruciais e nevrálgicos de toda a história da humanidade desde o seu nascedouro: a busca do poder.

Esse poder encontra-se latente em toda a peça, embora nem sempre revelado, ficando perceptível, às vezes, somente através do discurso subjacente que não se realiza ao nível da denotação.

Tal poder tem diversas representações ao longo de todo o texto e encontra-se colocado em parcelas significativas em vários de seus personagens, evidenciando relações claras, ou até mesmo insuspeitadas, no plano da aparência suscitada pela palavra.

A queixa dos personagens é constante nos diálogos, surgindo em cena por meio do que cada um representa em termos de poder. Sobre esse aspecto, um elemento de forte ligação entre os personagens 
principais da trama, o ciúme, pode ter sua inferência de correlação descrita pelo quadro seguinte:

\begin{tabular}{|l|l|l|}
\hline \multicolumn{1}{|c|}{ A } & & \multicolumn{1}{c|}{ B } \\
\hline DURAN / VITÓRIA & têm ciúmes de & MAX / TERESINHA \\
\hline TERESINHA & tem ciúmes de & MAX / LÚCIA \\
\hline MAX & tem ciúmes de & DURAN / PROSTITUTAS \\
\hline GENI & tem ciúmes de & DURAN / MAX \\
\hline CHAVES & tem ciúmes de & DURAN / MAX \\
\hline LÚCIA & tem ciúmes de & TERESINHA \\
\hline
\end{tabular}

Tanto na coluna $\mathrm{A}$ quanto na $\mathrm{B}$, seja qual for a posição de cada um dos personagens, todos têm em si a responsabilidade de encarnar o poder, o poder que é a busca de todos individualmente.

Esse ciúme é exatamente a exteriorização daquilo que constitui o desejo e o medo de perder ou de não alcançar o objeto desse desejo.

Dessa maneira, ao mesmo tempo que cada um, de um jeito ou de outro, representa o poder buscado e desejado pelos outros, é, ao mesmo tempo, um desejante com ciúme da parcela de poder que está no outro e temeroso da perda de sua própria parcela.

Duran e Vitória não se antagonizam nessa relação de ciúme, porque fizeram do seu casamento um negócio sólido, estruturado numa sociedade altamente lucrativa, na qual ambos têm uma importante e essencial participação, em termos de administração e força de trabalho. Eles mesmos o afirmam:

VITÓRIA - Teresinha, duas pessoas podem até se amar que nem nas novelas. Só que na vida real, se você ama uma pessoa, é lógico que não vai casar com ela. Casa com qualquer outro. Veja teu pai e eu. Como é que esse casamento durou esse tempo todo? Aqui ninguém ama nem desama.

DURAN - Nem fede nem cheira. 
VITÓRIA - Nem bate nem alisa. Então é casamento pra vida inteira. É pão pão, queijo, queijo. É um tijolo. DURAN — É sólido como um banco. (p. 82/83)

Já com relação a Max e Teresinha, a situação muda de figura. Max (cujo sobrenome, Overseas, caracteriza bem a relação com o elemento estrangeiro/imperialista e dá a razão maior do antagonismo) representa uma parcela de poder que aflige o casal e os faz, identicamente, invejar e temer o sucesso do contrabandista.

Assim é que, ao se referirem a Max, em qualquer situação, sempre o chamam de "ladrão", "bandido", "contraventor", "cangaceiro", "canalha" e outras expressões de igual ou pior teor. Contudo, cada referência feita a si mesmos é sempre realizada através de falsas verdades, eufemismos (o bordel é tratado por "butique dos Arcos") e metáforas que escondem, atrás de sua face aparente, um real outro, tão bandido quanto aquele de Max.

VITÓRIA - (Levanta-se) - Duran, o nosso nome está manchado. Uma vida inteira construindo uma reputação de dignidade e decoro, e da noite pro dia cai tudo por água abaixo!... (p. 47)

VITÓRIA - ... Só fico vendo como é inútil a gente tentar ser honesta neste mundo, Duran. Adiantou alguma coisa ser cidadão exemplar? Adiantou ser rotariano, adiantou?... (p. 48)

DURAN - Diga à tua filha que eu não faço acordo com marginal... (p. 88)

VITÓRIA - Se há uma coisa que nunca te faltou nesta casa foi educação cristã... (p.88)

DURAN - ... Denunciar criminosos é dever de todo cidadão honesto... (p. 149)

DURAN - Minha maneira de contribuir para a redução da marginalidade é empregar mil quatrocentos e trinta e dois funcionários fixos. Além de outros dez mil que eu ajudo aqui e ali. Mas você não, você tá tingindo os subúrbios com o sangue dos mendigos e dos adversários. Não adianta, Chaves, você não me enquadra. A minha bíblia é a Constituição da República e as leis trabalhistas são o 
meu breviário. Você já ouviu falar em lei? Em Constituição? (p. 149)

Com relação a Teresinha, existe o temor de que seu casamento possa provocar um enfraquecimento no poder que ostentam:

DURAN - ... Mas daí a casar vai um passo muito grande. Já mexe com a minha vida! Interfere no meu patrimônio! (p. 38)

O temor de um esfacelamento financeiro é claramente confessado adiante:

DURAN - Teresinha é o nosso maior investimento, Vitória! Ninguém aqui criou essa menina pra mulher de malandro não! O que a gente aplicou nela, é pra futura mulher de ministro de Estado, pelo menos... (p. 38)

DURAN - Queria acreditar nisso, Vitória, mas eu tenho medo. Em nossa família não pode caber um sanguessuga. (p. 39)

Posteriormente, a apreensão aumenta. Casando-se com Max, ela se transforma em ameaça real, concreta, pois não só se casa à revelia dos pais, como seu marido representa o inimigo temido e odiado. Esse passo dado por Teresinha, que equivale a uma adesão ao inimigo, significa, na verdade, um ato de traição, pois embora se esforce por parecer ingênua e alheia às falcatruas e sujeiras do seu amado (sua apresentação aos bandidos no covil, por exemplo, dá-se através de uma canção calcada na famosa canção infantil que leva o nome da personagem, com versos em claro duplo sentido), Teresinha tem consciência das atividades de Max. Acontece, porém, que seu desejo é alçar-se a um poder maior que o de seus pais e Max representa uma conquista importante para o alcance desse objetivo.

Mais adiante, ela chega bem perto disso, ao aproveitar-se da prisão de Max, para assumir as rédeas de seus negócios. Negócios que, sendo Max morto pela justiça de Chaves (pressionado por Duran), passarão inteiramente ao seu domínio, conferindo-lhe o poderio almejado e colocando-a em uma posição ideologicamente semelhante, ainda que conflitualmente antagônica à dos pais. 
Essa atitude de Teresinha, a traição, leva-a a aproximar-se de outro personagem, o homossexual Genival (Geni), pois, pelas mesmas razões de ânsia de poder, sendo ele empregado de Max, a quem obviamente teme e inveja, Geni, num jogo duplo permanente, numa contínua dissimulação da verdade, escudado numa aguda ironia, mantém relações comerciais e falsamente amigas com Duran e Vitória, terminando também por trair Max.

O casamento de Duran e Vitória é uma comunhão empresarial que os impulsionará à identificação quanto ao desejo e quanto ao encargo em direção à obtenção desse desejo. Max, por sua vez, mostra-se como o objeto desse desejo, objeto a ser destruído, eliminado. Chaves, representante do poder policial, mancomunado e devedor de Duran, a quem é forçado a se submeter, torna-se o encarregado ideal para cumprir esse desejo. E é justamente Vitória quem dá a idéia:

VITÓRIA - ... Ah, eu quero que esse homem morra! Quero ver o corpo desse homem crivado de chumbo, num barranco do rio da Guarda!

DURAN - O que é que você disse, Vitória?

VITÓRIA - Isso mesmo. Cheio de urubu disputando as tripas dele!

DURAN - Vitória, você disse tudo! Vou ter uma conversinha já já com o inspetor Chaves. Ele tá me devendo as calças e chegou a hora de acertar as contas. (p. 48)

Quanto a Geni, seu jogo é sempre duplo ao longo de toda a peça. Ele tanto traz as informações (sempre camufladas, dissimuladas no diálogo), quanto alerta o casal a respeito do quebra-quebra no bordel e do casamento de Max com Teresinha. Geni não está nem de um lado nem do outro. Só está onde mais puder lucrar. Essa duplicidade, essa atitude camaleônica, por assim dizer, está presente em quase todos os instantes de sua fala mascarada.

GENI - ...Diz que a família dela tem muito dinheiro. DURAN - Café?

GENI - Não, parece que é gado. Os negócios da família dela, eu não entendo não, parece que são uns comércios meio atrapalhados... Os pais dela moram 
por aqui mesmo, na Lapa, que é onde eles têm esses comércios.

DURAN — Gado? Na Lapa? Então tá explicado! Essa mocinha fina é filha dum açougueiro.

GENI - Não é açougueiro não. Diz que ele trabalha com carne viva. Mas apesar disso, apesar dos pais serem bem ordinários, diz que a filha saiu diferente e que foi muito bem educada. (p. 45)

O cinismo, que é marca registrada de Geni, tem um ponto alto na cena, quando ele revela, depois de muitos rodeios, o nome da noiva de Max:

GENI - Ah, o nome da noiva... Como é mesmo o nome da noiva? Ah, já sei! O nome da noiva é Teresinha Fernandes de Duran. (Duran e Vitória ficam paralisados) - Engraçado, né? Que coincidência. Eu nem tinha notado... Com esse sobrenome, será que a moça não é parenta de vocês? (p. 46)

A cena 4 passa-se sob a expectativa de uma passeata, que não passa de um ardil, um estratagema de Duran, uma peça na caça a Max. Tendo fracassado na primeira tentativa de cumprir esse desejo (Max fugira da cadeia, onde fora parar por delação de Geni, com o auxílio de Lúcia, a própria filha do inspetor), Chaves se vê pressionado e fortemente ameaçado por Duran, que se aproveita dos crimes arbitrários cometidos por ele em nome da lei, para se pôr em posição de carrasco.

DURAN - ... Como é que o Hitlerzinho da Lapa vaise safar desta, hein? Calcule a indignação da opinião pública quando forem denunciadas as atrocidades cometidas por um certo inspetor Chaves, mais conhecido por Tigrão, o facínora...

CHAVES - Não, Duran, por favor, chega!

DURAN - Liquidou o bandido?

CHAVES - Eu fiz o possível e o impossível!

DURAN - Vais ter um nobre destino. Igualzinho à dona Maria Antonieta. A não ser, é claro, que você use a cabeça e me apresente a cabeça de teu amigo. Aí, quem sabe, dá-se um jeitinho, né? Mas acho que já nem dá tempo, inspetor. (p. 151/152) 
Adiante, Geni entra inesperadamente na cena, como é seu costume. Mais uma vez, trai Max, revelando seu novo esconderijo e, portanto, colaborando decisiva e eficazmente para a eliminação dele. Max é o objeto do desejo de Duran e Vitória, que Chaves se vê obrigado a executar, para não perder o poder que possui. Mas Geni só dá essa informação tão valiosa para o sujeito, depois de uma intensa bajulação e de uma barganha cínica e irônica, bem ao seu feitio.

Seu exibicionismo, seu mau-caratismo são latentes. Ele, na realidade, só quer garantir seu lucro próprio. Mesmo que tenha de sacrificar seu patrão e amigo para conseguir seu intento. O que o aproxima de Teresinha, mas não de Chaves, que é também amigo de Max e o trai, só que mevido mais pelo medo de perder seu poder que pelo desejo de adquirir mais poder.

Depois de muito simulacro e de já ter recebido o cheque que exigira, Geni leva ao ápice o seu deboche, resolvendo cantar para eles, antes da grande revelação.

A canção "Geni e o Zepelim", que assume as características de uma canção autobiográfica, revela o jogo duplo de Geni também na área da sexualidade:

“...Foi assim desde menina

Das lésbicas, concubina

Dos pederastas, amásio.

É a rainha dos detentos

Das loucas, dos lazarentos

Dos moleques de ginásio

E também dá-se amiúde

Aos velhinhos sem saúde

E às viúvas sem porvir..." (p. 161)

Desvendando em sua fantasia o jogo duplo da bissexualidade, Geni, nessa canção, tem ainda seu duplo demonstrado na oposição pecadora / redentora em relação à cidade e sua população ameaçada pelo Zepelim.

Nessa soma de elementos que levam à percepção do caráter de Geni, não pode deixar de ser levada em conta a rubrica do autor, no final da cena, após a revelação do novo esconderijo de Max: 
(Todos saem correndo, exceto Geni que senta-se na poltrona, toma um gole de conhaque e se abana com o cheque; cai a luz em resistência.) (p. 164)

Esse gesto, essa atitude, levam à confirmação de que Geni atua na narrativa como um jogador que trapaceia o tempo todo, sempre ocultando, atrás de um discurso aparente, suas verdadeiras e egoísticas intenções.

Na cena 6, que antecede a cena final, Max está novamente na cadeia e a cena, bastante curta, torna-se o momento da concretização do desejo de Duran e Vitória. Nela, Chaves deverá liquidar Max. Só que, dessa vez, Vitória, que não participa da cena, fica com a responsabilidade da paralisação da passeata, exigência de Chaves em troca da eliminação de Max. Segue-se uma discussão entre Duran e Chaves, a respeito do que deve ser feito primeiro, se a interrupção da passeata ou a execução de Max.

CHAVES - Eu tenho o maior prazer em executar o meu amigo. Mas tem que desmanchar a passeata antes.

DURAN - Que é isso, Chaves? Não confia em mim? CHAVES - E tu? Não confia em mim?

DURAN - Não.

CHAVES - Então empatou zero a zero.

DURAN - Assim não dá, Chaves. Alguém tem que agir primeiro.

CHAVES - Eu tô com a arma engatada e na mira, Duran. (Aproxima-se de Max) - Tu fica ao meu lado. $\mathrm{Na}$ hora exata que esse esporro sossegar, tu me cutuca que eu dou o teco. (p.173/174)

De repente, porém, nada se concretiza, pois o texto dá uma reviravolta e parte para a arbitrariedade total, instalando na cena a perplexidade, a surpresa, a desmistificação do próprio drama.

A representação é subitamente suspensa e segue-se uma grande confusão, que caminha para um operístico epílogo, no mesmo estilo do prólogo, enquanto o personagem João Alegre, o malandroautor, posa ao volante de um conversível modelo anos 40 . 


\section{Referências bibliográficas}

BRABANT, Georges-Philippe. Chaves da Psicanálise. Tr. Themira de Oliveira Brito e Vânia Didier Contrucci. 2. ed. Rio de Janeiro: Zahar, 1977.

BUARQUE, Chico. Ópera do Malandro. São Paulo, Livraria Cultura, 1978.

UBERSFELD, Anne. Lire le Théâtre. 2. ed. Paris: Éditions Sociales, 1982. 